Review

\title{
Barcoding of Plant Viruses with Circular Single-Stranded DNA Based on Rolling Circle Amplification
}

\author{
Holger Jeske \\ Department of Molecular Biology and Plant Virology, Institute of Biomaterials and Biomolecular Systems, \\ University of Stuttgart, Pfaffenwaldring 57, 70550 Stuttgart, Germany; holger.jeske@bio.uni-stuttgart.de; \\ Tel.: +49-711-685-65070
}

Received: 2 August 2018; Accepted: 30 August 2018; Published: 31 August 2018

\begin{abstract}
The experience with a diagnostic technology based on rolling circle amplification (RCA), restriction fragment length polymorphism (RFLP) analyses, and direct or deep sequencing (Circomics) over the past 15 years is surveyed for the plant infecting geminiviruses, nanoviruses and associated satellite DNAs, which have had increasing impact on agricultural and horticultural losses due to global transportation and recombination-aided diversification. Current state methods for quarantine measures are described to identify individual DNA components with great accuracy and to recognize the crucial role of the molecular viral population structure as an important factor for sustainable plant protection.
\end{abstract}

Keywords: geminivirus; nanovirus; satellite; RCA; RFLP; Circomics

\section{Introduction}

The symptoms of plant viruses, later known to contain circular single-stranded DNA, were already described in ancient times: 752 ACE, in a poem, and 1868 ACE, in garden literature [1-3]. Only in more recent decades have they become devastating pests in agriculture and horticulture due to intensified farming and global transportation of plant material, as well as recombination and pseudo-recombination (reassortment of genomic components) of viruses [4]. Geminivirus genomes consist of one ("DNA A-like") or two ("DNA A", "DNA B") DNA circles of, in total, 2500-5200 nucleotides (nt); nanovirus genomes consist of more (>6) components, each of a smaller size (900-1100 nt). Geminiviruses may have adopted DNAs from nanoviruses (named alpha-satellites, here abbreviated "aSat") or of other unknown origin (especially the beta-satellites; "bSat"), and delta-satellites, which may or may not be essential for symptom development. For diagnostic purposes, it is necessary to emphasize that geminiviruses may be prone to generate defective DNAs ("D-DNA") depending on the virus and the host plant. If D-DNAs interfere with the multiplication of the parental virus, which is not necessarily the case, they are also referred to as "defective interfering, DI-DNAs". The detection of single-stranded (ssDNA) circles by RCA/restriction fragment length polymorphism (RFLP) in a plant is a first good diagnostic hint for a virus infection in most plants, but some plant species harbor small circular mitochondrial plasmids that may be misinterpreted as viral agents. Such plasmids might be useful as internal standards. For the practical purposes of plant protection, it may be necessary to discriminate between potentially infectious components and defective ones, which may occur as a cocktail in field isolates. Under certain circumstances, the accumulation of DI-DNAs may protect the plant from an infection by more severe viruses, and it may thus be a wrong decision to remove these plants, in particular for perennial species. For quarantine measures in general, however, it is more of a cautious measure to eradicate all circular viral ssDNAs from the plant material in stockbreeding. A few reports have appeared during the last years that 
discuss seed transmission of geminiviruses controversially [5-7]. In general, sexual crossing is an excellent way to purge breeding material. Vegetative propagation and grafting, however, promote virus dissemination very efficiently. More sophisticated diagnostics are necessary for these cases (such as cassava, sweet potato, and ornamentals), since the viruses may be distributed unequally within a plant and multiply differentially under certain environmental conditions (temperature and light intensity, quality, or period). In spite of some progress in the field of conventional breeding and genetic engineering to combat these viruses, quarantine measures to restrict their spread are still the most effective way for plant production. Immunological and PCR-based techniques have been widely used to detect the viruses, but rolling circle amplification (RCA), in combination with restriction fragment length polymorphism (RFLP) analyses, have become more popular during the last decade due to their simplicity, accuracy and lack of a priori knowledge, which will be explained in detail in this review.

The molecular biology of geminiviruses, nanoviruses, and their satellites has been reviewed previously [8-15]; a taxonomy profile for geminiviruses has been published recently [16] separating nine genera currently. The nomenclature of aSats has become more and more complex, with an ICTV-approved family Alphasatellitidae now including two subfamilies (Geminialalphasatellitinae and Nanoalphasatellitinae) [17].

\section{The Broad Practical Application of RCA}

A literature survey on the Web of Science for the years 2004 to 2018 yielded 146 papers in which RCA was mentioned explicitly for geminiviruses, mastreviruses, begomoviruses, curtoviruses, and nanoviruses [2,18-160]. It showed a representative sample for the broad application of the technique for various plant hosts, environmental specimens and viruses for various countries worldwide in fundamental as well as applied science, as summarized in Table S1. Many more excellent publications have appeared in this context, mainly in the field of classification and taxonomy of known and newly detected ssDNA viruses, as well as of resistance breeding and biotechnology, which cannot be cited here due to space limitations. The reader is referred to comprehensive overviews for those aspects [161-170]. The following review rather tries to focus on certain aspects of RCA diagnostics to describe the state-of-the-art technique and its unique advantages.

\section{Sampling Is Simple}

In particular for tropical and subtropical countries, where most geminiviruses and nanoviruses are pests, an important prerequisite for reliable virus detection is the collection of plant material and the preservation of its DNA. The simplest way to do this is by harvesting fresh young leaves without any sign of necrosis, if possible, and placing them immediately between two sheets of blotting paper to allow for slow drying at room temperature. The samples are stored dry at room temperature in the dark to avoid hydrolytic DNA base deamination and oxidation and they may be analyzed several years later for RCA/RFLP without any loss of resolution $[2,26,72,96]$. This easy technique has proven to be successful for various plant species, including woody perennials. More elaborate and expensive sampling and storage variants by means of Whatman FTA ${ }^{\mathrm{TM}}$ cards have been used to avoid any risk of virus spread [22], but the dried samples of plant sap on simple paper may be generally regarded as safe, since insect vectors (whiteflies, leafhoppers, aphids) are needed for further spread of geminiviruses and nanoviruses, which will not feed on this material at all.

\section{Extraction of Nucleic Acids}

Clipping off a small disk from a dried leaf, e.g., with an Eppendorf tube lid, yields sufficient material for several RCA/RFLP analyses. Extraction of nucleic acids based on the cationic detergent cetyltrimethylammonium bromide (CTAB) is reliable for most plants, even those which are technically recalcitrant due to mucilage and other secondary plant components [19]. Including antioxidants may be necessary for certain plants that react with necrosis and browning, such as some vetch and potato variants. After chloroform extraction and alcohol precipitation, the sample is ready for RCA. 
Several attempts to increase the efficiency of the reaction by further purification of the nucleic acids failed to improve the detection [19]. Heating the sample to $65^{\circ} \mathrm{C}$ for a short period (10 min) assists in dissolving the nucleic acids, denatures residual proteins, and minimizes the breakage of viral ssDNA rings. For double-stranded DNA (dsDNA) such as plasmids, protocols frequently recommend a heating step at $95^{\circ} \mathrm{C}$ to nick one strand of the ring and denature the DNA to allow for hybridization of primers; this is, however, counterproductive for circular ssDNA viruses (see below). Most importantly, it generates a high background of RCA templates of the (linear) host DNA, which should be excluded from the further process.

\section{Run-Off and De Novo Primed Replication}

For an optimal usage of the RCA reaction, it is necessary to consider some basic prerequisites and peculiarities of geminiviruses and nanoviruses (Figure 1). In a leaf sample, the majority of the viral DNA is usually circular ssDNA. However, substantial amounts are engaged in replication, leading to heterogeneous ssDNA and dsDNA forms, as well as combinations of both. In one-dimensional gels subjected to Southern analysis with virus-specific probes, this DNA portion is underestimated because it forms a smear signal after hybridization. Two-dimensional gels have shown a more appropriate representation of the multitude of DNA intermediates for various geminivirus-host combinations [171-182]. These intermediates for complementary strand replication (CSR), rolling circle replication (RCR) and recombination-dependent replication (RDR) can serve directly as templates for run-off RCA. Their direct use would be prevented if the sample was heated to $95^{\circ} \mathrm{C}$ beforehand. The only form which would need nicking to start replication is the usually smaller portion of covalently closed circular (ccc) dsDNA. Viral ssDNA needs a primer for further propagation; this can be a random hexamer that is added to the reaction mixture. Due to the intrinsic $3^{\prime}-5^{\prime}$ exonuclease activity of the Phi 29 polymerase, the $3^{\prime}$ end of the primer should be protected by phosphoro-thioate-linked nucleotides for optimal use [183]. In addition, endogenous RNAs such as small interfering RNA (siRNA) and viral transcripts can probably serve as primers as well, and hybridize to the ssDNA at $65^{\circ} \mathrm{C}$, possibly explaining why a further purification of the crude nucleic acids may be less efficient for the final outcome of the tests.

The primary product of RCA is a complex mixture of ssDNA and dsDNA, building a huge network due to the high processivity and strand-displacement activity of the Phi 29 polymerase (Figure 1). Multiple priming on a single circular molecule can yield pinwheel-like products. For efficient RFLP analyses, it is important to note that the primary ssDNA products need a second strand replication to be cleavable by the restriction enzymes (Figure 2). The relative proportion of template DNA and the added phosphorothioate-modified primers (usually in surplus) are therefore crucial for the outcome of the assay. Infected plant samples with very high concentrations of ssDNA may need a serial dilution in two-fold steps to obtain the optimum concentration of dsDNA RCA products and a clean RFLP pattern. Incomplete digestion is frequently caused by incomplete second strand replication and results in a misleading complex fragment pattern. 


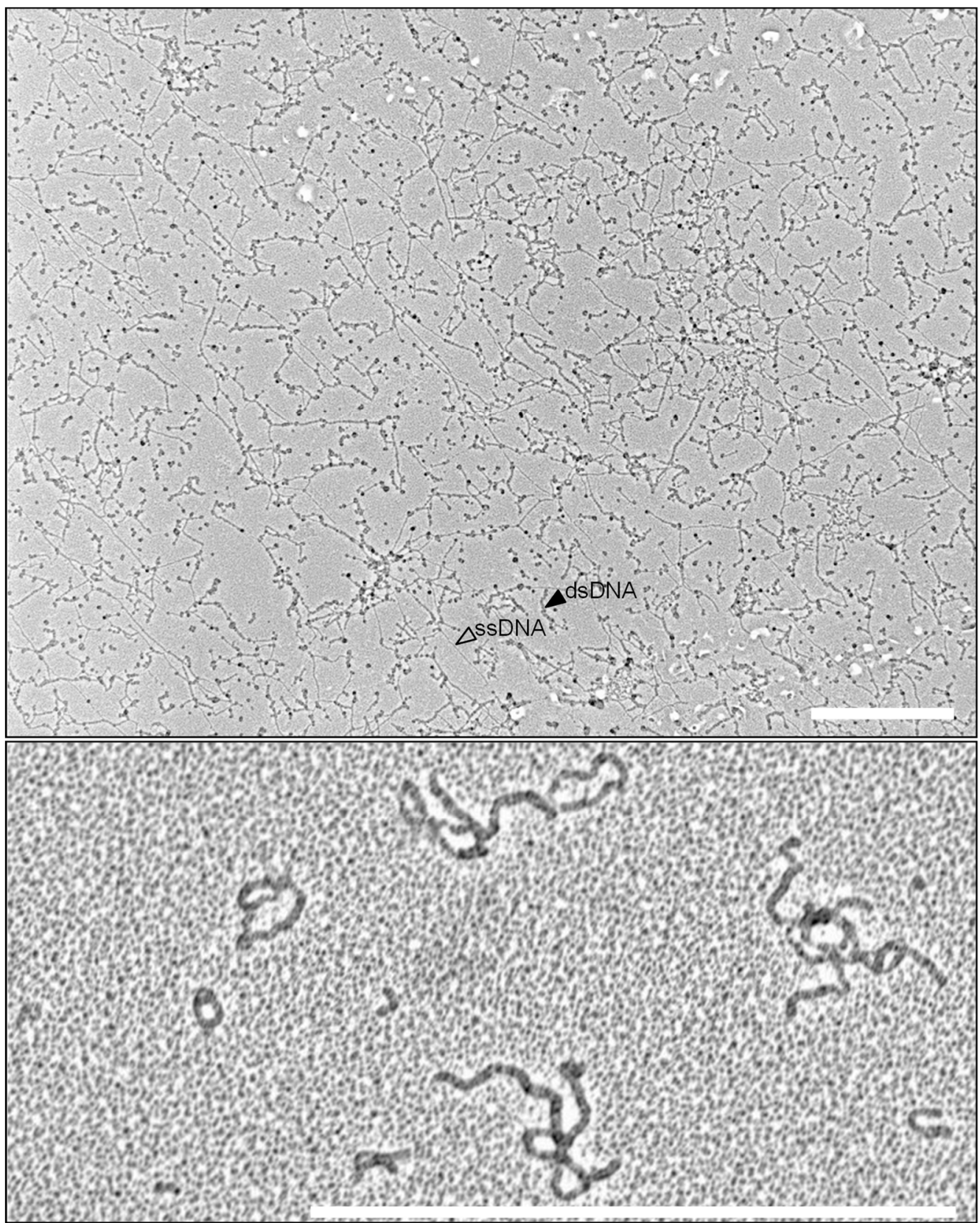

Figure 1. African Cassava Mosaic Virus TempliPhi rolling circle amplification (RCA) product spread on a cetyltrimethylammonium bromide (CTAB)-activated carbon film, contrast is obtained by $\mathrm{Pt}$ evaporation, shown at two magnifications $(\mathrm{bar}=1 \mu \mathrm{m})$. Note the pinwheel structures, indicative of multiple-primed circular DNA (asterisk). 
1. primer annealing

2. complementary strand replication
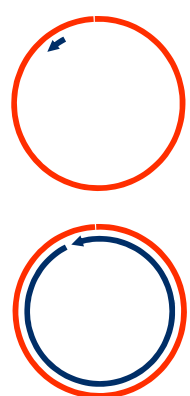

3. displacement replication
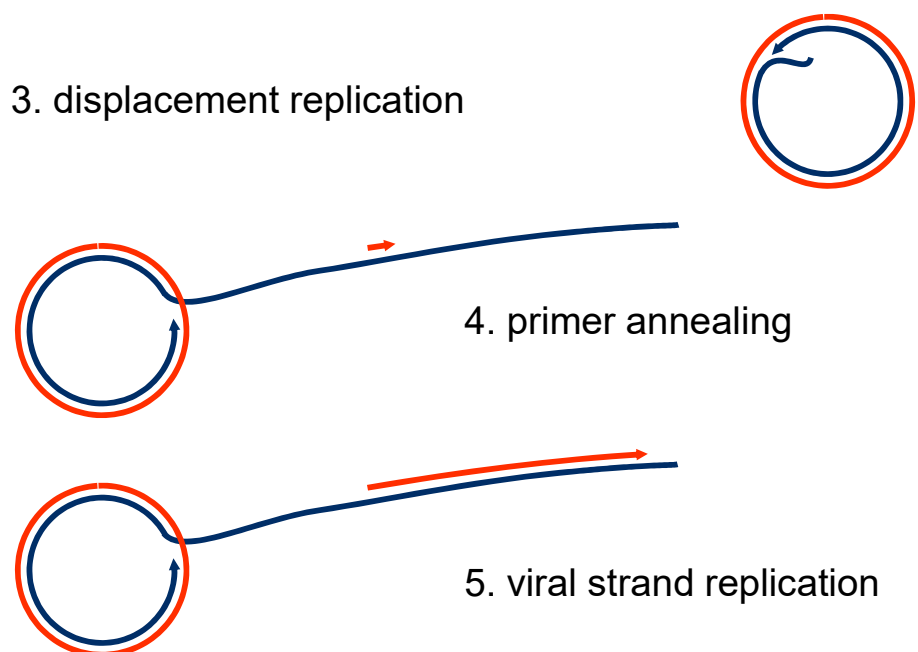

Figure 2. Steps of RCA on geminiviral single-stranded (ssDNA). Primers may be RNA or DNA of plant origin, or random hexamer phosphorothioate-protected primers added to the reaction mixture. Colours: red viral strand, blue complementary strand. Similar intermediates are generated in vivo during geminiviral replication modes, in CSR, RCR, or RDR.

\section{The Best Choice of the Restriction Enzymes}

Depending on the virus to be detected, appropriate restriction enzymes have been used, mostly HpaII and Sau3A. For a genome size of 2500-5000 nt, enzymes that recognize 4 nt yield a sufficient number of fragments to differentiate genomic components, as well as different viruses in general [72]. The resulting fragments are usually separated in agarose $(>2 \%$; for $>250 \mathrm{bps})$ or polyacrylamide $(>5 \%$; for $<1000 \mathrm{bps}$ ) gels and are stained after the electrophoresis by ethidium bromide or SybrGold $[2,19,184]$. Slower migration for longer time periods during electrophoresis extends the range of resolution for a greater range of fragment sizes. Under optimal experimental conditions, the migration distances in the gel are reliable estimates of the fragment sizes (see below); anomalous migration behavior has only been observed in very few cases, probably due to a bent conformation of the particular DNA fragment [185]. In such cases, the choice of another restriction enzyme solves the problem.

The power of resolution may be enhanced by Southern blot hybridization using component specific probes, which also visualize the multitude of variants in the pool of viral DNAs and/or incompletely cut RCA products $[2,96]$.

The best diagnostic fragments are those that are sufficiently different between various DNA components, independently of the size of the fragments, which only requires the choice of optimal gels. For statistical reasons, most fragments do not fulfill this prerequisite immediately. The most frequent fragment sizes will be more similar between different viruses just by chance. It is, therefore, interesting to analyze the basis of variability with reference to fragment size and frequency in the database of geminiviruses. In 2017, all entries for geminiviruses in the GenBank were retrieved, and 9140 non-redundant entries for individual components from this database selected to digest them 
by in silico restriction using Python scripts. The nucleotide contents were analyzed for the most prominent genera (Begomovirus, Curtovirus, Mastrevirus) (Table 1).

Table 1. Occurrence of nucleotides in the different geminivirus genera $(\%) ; n$, the number of data base entries analyzed.

\begin{tabular}{cccccccccccccccc}
\hline Genus & \multicolumn{1}{c}{ Mean Length } & \multicolumn{4}{c}{ Mean Frequencies } & \multicolumn{4}{c}{ Entries } & \multicolumn{4}{c}{ Standard Deviations } \\
\hline & & $\mathrm{A}$ & $\mathrm{C}$ & $\mathrm{G}$ & $\mathrm{T}$ & $\mathrm{A}+\mathrm{T}$ & $\mathrm{G}+\mathrm{C}$ & $\mathrm{n}$ & $\mathrm{A}$ & $\mathrm{C}$ & $\mathrm{G}$ & $\mathrm{T}$ & $\mathrm{A}+\mathrm{T}$ & $\mathrm{G}+\mathrm{C}$ \\
Begomovirus & 2719 & 26.6 & 20.2 & 23.1 & 30.1 & 56.6 & 43.3 & 7001 & 1.1 & 1.5 & 1.6 & 1.5 & 2.1 & 2.1 \\
Curtovirus & 2932 & 28.2 & 17.3 & 23.1 & 31.4 & 59.6 & 40.4 & 193 & 1.1 & 0.4 & 1.1 & 0.6 & 1.4 & 1.4 \\
Mastrevirus & 2684 & 25.4 & 22.6 & 25.8 & 26.2 & 51.6 & 48.4 & 1619 & 1.4 & 1.9 & 1.0 & 1.7 & 2.4 & 2.4 \\
Other & 2708 & 26.5 & 22.6 & 23.5 & 27.4 & 53.9 & 46.1 & 327 & 2.6 & 4.3 & 2.1 & 3.7 & 4.9 & 4.9 \\
\hline
\end{tabular}

A bias towards an enhanced T frequency over the expected frequency has to be noted for begomoviruses $(30.1 \%)$ and curtoviruses $(31.4 \%)$, possibly the result of a high deamination rate leading to $\mathrm{C}>\mathrm{T}$ transitions, as observed experimentally $[180,186]$. Consequently, A\&T-rich recognition sequences of restriction enzymes should yield more and smaller fragments. The resulting statistics for all available restriction enzymes is provided in the Supplementary (Figures S1 and S2), with an example given for the recognition sequence AATT (MluI) (Figures 3 and 4). This sequence is clearly overrepresented for begomoviruses, and underrepresented for mastreviruses (Figure 3). The distribution along the genome (Figure 4) is mostly random with only few hot spots for begomoviruses in regulatory DNA elements (such as promoters, 2500 to $200 \mathrm{nt}$, and terminators, $\sim 1000$ to $1200 \mathrm{nt})$. As a consequence of these distributions, more and smaller fragments can be obtained for begomoviruses than for mastreviruses, and the chance to detect diagnostic fragments upon comparing the RFLP products of all components under consideration increases. For novel projects, the data provided in the Supplementary material may be a guide to choosing the best restriction enzymes. 

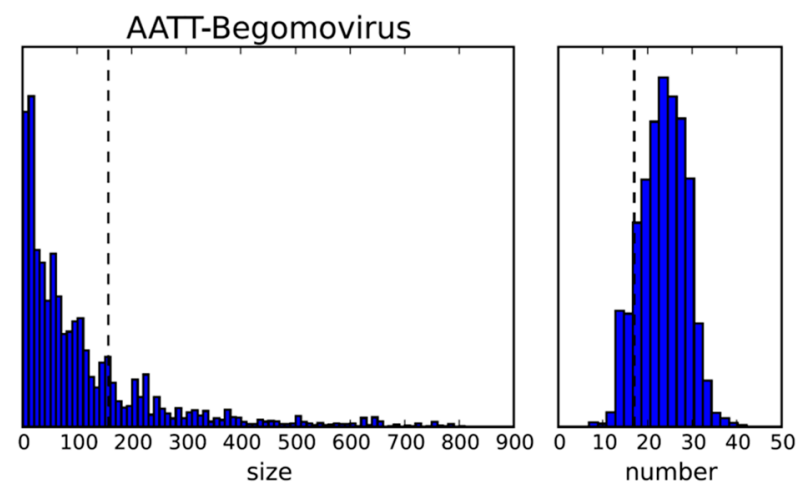

AATT-Curtovirus
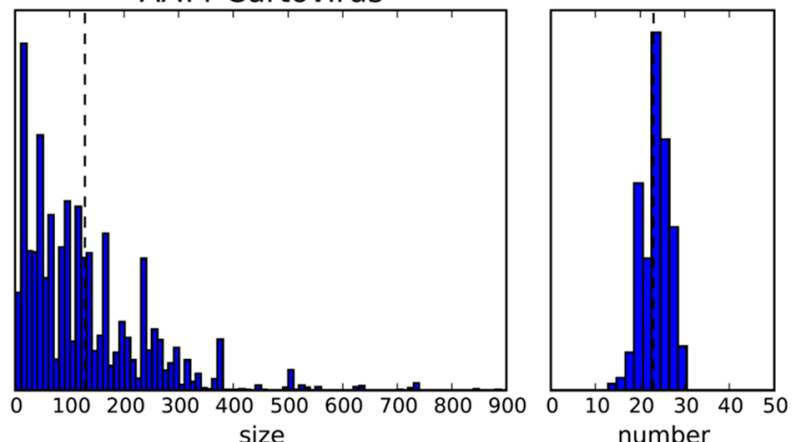

AATT-Mastrevirus
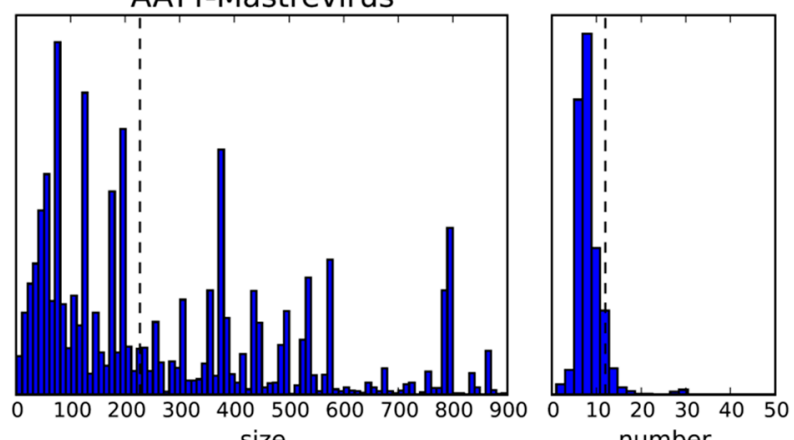

AATT-Rest
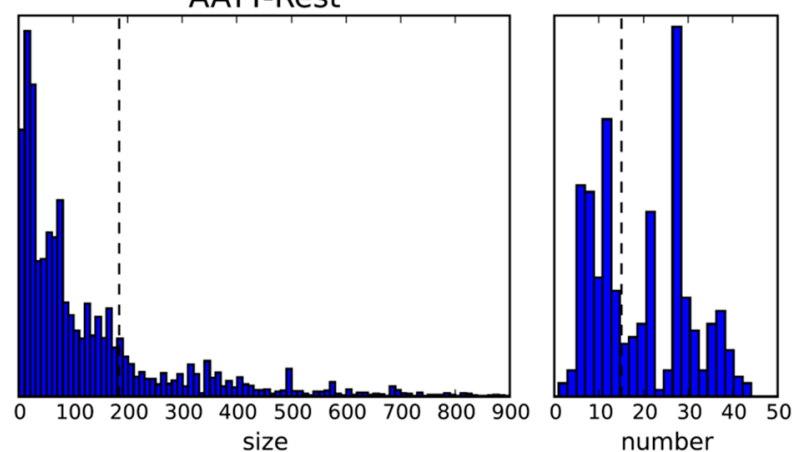

Figure 3. Statistics of the restriction enzyme recognition sequence AATT (for MluI) for the indicated genera and all others (rest). Left column for fragment size, right column for distribution by number of fragments for the indicated genera based on the data as shown in Table 1. Stippled lines indicate the expected value, calculated on the basis of the nucleotide frequencies. $y$ axis: relative frequency; size in bp. The whole data set for all four nucleotides recognition sites is given in Figure S1. 


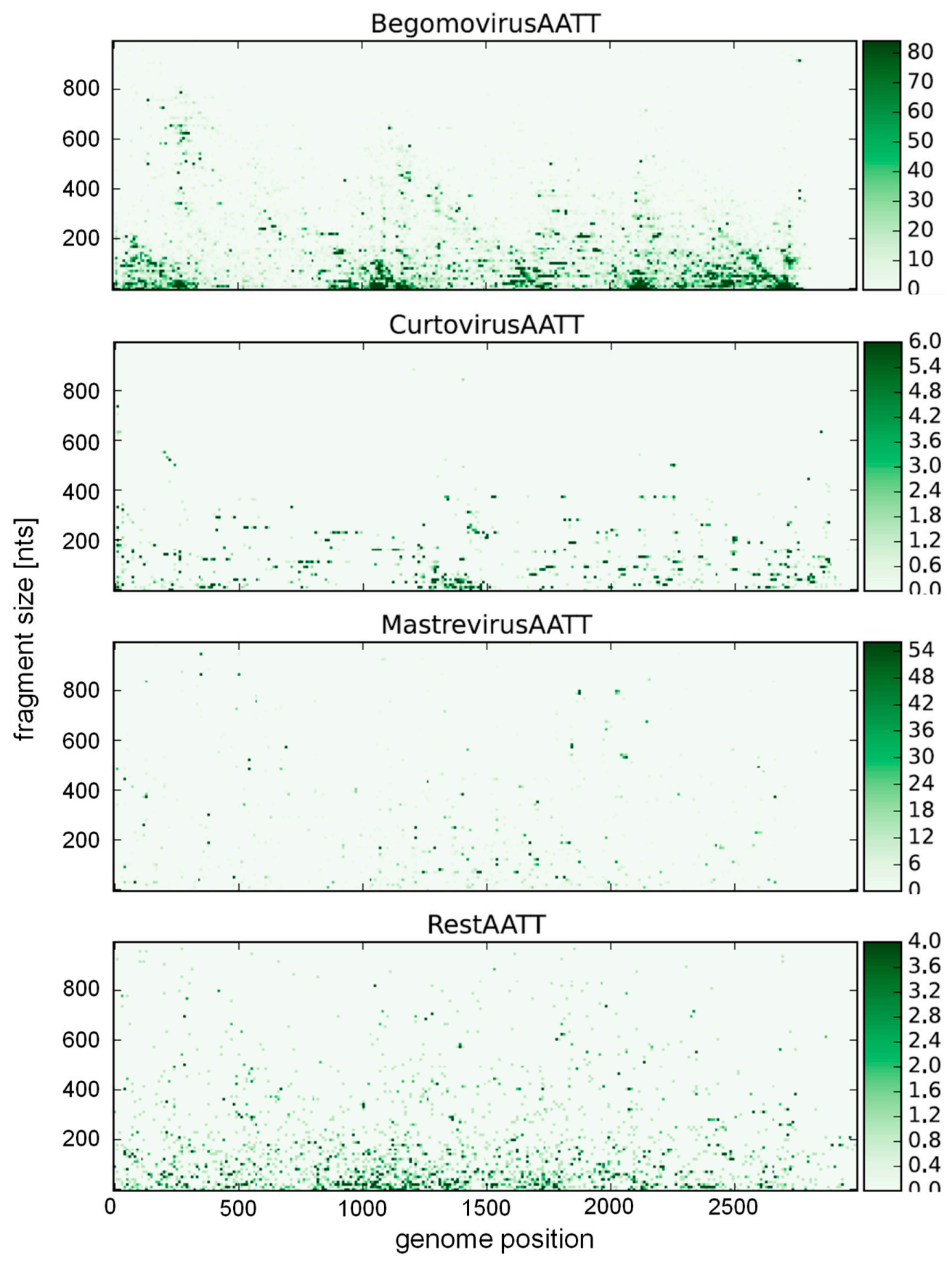

Figure 4. Statistics of the restriction enzyme recognition sequence AATT (for MluI) as in Figure 3, but relating fragment sizes to genome position. Dot intensity indicates frequency. The whole data set for all four nucleotides recognition site is given in Figure S2.

\section{Standardization to Determine Fragment Sizes}

An accurate determination of the fragment sizes obtained by gel electrophoresis is crucial to discriminate between matching and non-matching fragments, in order to differentiate viral components. Usually, a log relationship between the molecular weight and the migration distance (normalized as retardation factor (Rf) values) can be obtained in the central part of a gel, but for the complete gel, a sigmoid curve gives a better fit [2,72] (Figure 5, Table S2). The inverse function to linearize a sigmoid curve is obtained by a Probit analysis [187], which can be performed easily with the Excel function $[=5+\operatorname{NORM} . \mathrm{INV}(\mathrm{D} 5 ; 0 ; 1)]$ (Table S2) This approach optimized the log-lin fit $\left(\mathrm{R}^{2}=0.991\right)$ and led to 
an error for fragment size determinations below 3\% (Figure 5) in a large variety of sample analyses irrespective of virus, plant and gel in our lab [72] (Table S2).

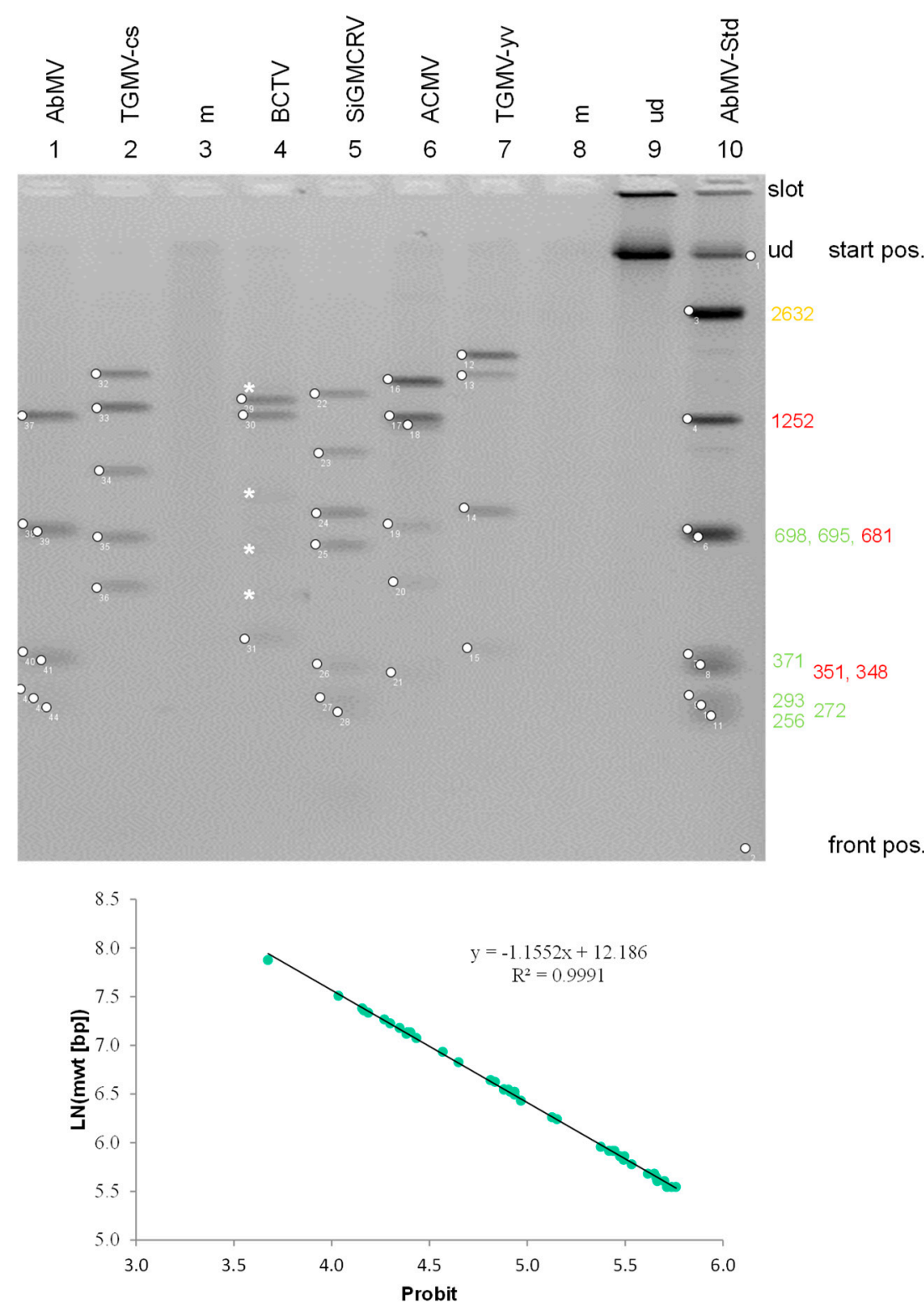

Figure 5. Accuracy of the fragment size determination. RCA/RFLP (HpaII) of various geminivirus samples (Abutilon mosaic virus, AbMV; tomato golden mosaic virus-common strain, TGMV-cs; beet curly top virus, BCTV; Sida golden mosaic Costa Rica virus, SiGMVCRV; African cassava mosaic virus, ACMV; tomato golden mosaic virus-yellow vein, TGMV-yv) are compared with an AbMV standard (mixture of PstI- and HpaII-cut RCA products), mock-inoculated (m), and undigested (ud) of AbMV RCA product. Separation was performed in a $2 \%$ agarose gel and staining with ethidium bromide (inverse image presentation). The positions of genomic fragments (circles) were determined using Fiji (Image J), the corresponding migration distances in numbers of Pixel recalculated in Excel (lower graph) to relate the fragment sizes (in bp) in logarithmic scale to probit values. All data fit to a line with Pearson's correlation coefficient of $R^{2}=0.991$ corresponding to a mean error of 1.6 \pm 1.3 . Asterisks indicate fragments from defective DNAs of BCTV. Molecular weights (nt) for the standards are indicated on the right, yellow genomic size, red DNA A, green DNA B. Relative migration distance (Rf) values were determined in relation to the start and front positions. 
The appropriate standard fragments in each gel are absolutely necessary to reach this degree of accuracy. The use of RCA/RFLP products of sequenced viruses for comparison has been found superior to other marker restriction fragment mixtures. If a specific virus is suspected in the plant, the RCA products of this virus retrieved from cloned material may be sufficient and easy to compare for calibrating the analysis. If unknown viruses have to be compared to the electronic database, a broad range of fragment sizes for the standards is desirable. The RCA products of plasmids may be useful, or Abutilon mosaic virus (AbMV) DNA may be chosen, since this virus is available worldwide in botanical and market gardens [2]. AbMV is, in addition, an excellent training object, since the woody Abutilon plants, harbor mucilage and secondary metabolites that may be a challenge for beginners.

An incorrect assignment of a band in the gel to a fragment size is tested most easily by way of graphical evaluation (Table S2). The whole set of results can be scrutinized for internal consistency (Table S2), and corrected if necessary. The more bands are correctly assigned, the more accurate the determination of the remaining unsure bands.

If digestion with the restriction enzyme is complete for each component, the band intensities of the proper genomic fragments should follow a consistent molar series for each component. This can be graphically checked by scanning a lane by ImageJ software and judging the peak heights decline. Double and multiple bands for fragments with similar molecular weight can be identified, as well as products from D-DNAs, which can also be identified if samples from separate plants are compared, since they are usually different in different individual plants $[43,54,105]$. Some limits for the representation of single components in RCA pools have be reported for nanoviruses [188].

\section{Get the Unknown and Unexpected}

The major advantage of RCA, in comparison to PCR and immunodetection, is its ability to detect circular DNA molecules without any a priori knowledge. When viruses are imported into a new country, such as tomato yellow leaf curl virus (TYLCV) in the Americas [189] or Northern Europe, [95] and squash leaf curl virus (SLCV) in the Middle East [103], they can be recognized. Samples with aSats, which were believed to be restricted to the Old World before, were found in Brazil, Venezuela, and Cuba $[38,96,190]$. Moreover, mitochondrial plasmids were amplified from certain plant species [24,43]. Screening germplasm bank collections with RCA/RFLP, in particular for vegetatively propagated plants, with RCA/RFLP provides important precautions to prevent dissemination of geminivirus-infected material [43].

\section{Resurrection of Viruses}

Although the plain RCA products can be generally regarded as safe with reference to natural spread, it is possible to raise infectious viruses by biolistic inoculation of the RCA-amplified DNA to test plants under laboratory conditions $[19,36,68,178-180,184,186]$. This procedure has the advantage of preserving the whole population structure of a virus quasispecies $[180,186]$. In combination with the selection of fragments by gel purification, religation to circularize the DNA fragments, and a second RCA, a proper infectivity was obtained for viruses that were otherwise recalcitrant to bacterial cloning [184]. Only in rare cases is a linear fragment of genomic size sufficiently infectious using rub-inoculation, such as for ACMV [191]. Typically, partial dimers ("bitmers"), dimers, or the multimers of the RCA products without any further digestion are the prerequisite for replicational or recombinational release of unit length DNA circles inside cells, in order to retain redundant sequence regions [192].

If infectious DNA is to be cloned in bacterial plasmids, RCA products are digested by restriction enzymes at limited concentration or incubation time [27,57]. Fragments of sizes larger than genomic length are gel-purified and inserted into plasmids. Usually, limited cleavage of the RCA product with Sau3A (or MluI) and insertion into BamHI (or EcoRI) sites of the plasmids is generally applicable for all genomic components without a need to search for proper restriction enzymes. The versatile small agrobacterial plasmid pGreen [193] has been used for in planta delivery by stem inoculation or leaf 
infiltration with many viruses, aSats and plants $[57,68,72,108,124,179]$, but other Ti-based plasmids are used routinely as well.

\section{Get the Whole Sequence Information}

If some sequence information is known to deduce a specific primer, and if the plant under investigation is infected by a single virus, direct sequencing of the RCA product is the technique of choice to obtain the whole sequence of the virus components by primer walking [68,184], in addition to conventional cloning and sequencing. The resulting sequence will represent the master or consensus of the DNA population, ignoring the variability within the population, and may deviate from individual clones. In addition, several deep sequencing techniques have been applied directly to the RCA products (Circomics). Pyrosequencing had the advantage of longer reads, but more errors were also observed, in particular for homo-polynucleotide stretches [72,96]. Illumina sequencing exhibited a lower error rate and yielded less extended, but still sufficient, reads to determine the mutational variability within a viral DNA population, when proper plasmid controls were included to check the error rate with this technique $[2,180,186]$. Unexpectedly high proportions of D-DNAs were identified in addition. Recently, single molecule sequencing has been applied to many individual samples in a single assay [194]. This approach has a great advantage in the detection of intra- and intermolecular recombinant components.

For practical purposes, such as the identification of known viruses, direct sequencing of RCA products across the short segment of the most variable intergenic region in the virus component will be satisfactory for most applications. With the decreasing costs of commercial sequencing, this approach will outperform the RFLP analyses for cases of known conserved primer sequences, e.g., within the coat protein or Rep gene. The information thus obtained is much more precise and can be easily compared to the electronic databases.

For fundamental research, Circomics extends the view to the complexity of DNA virus variation and the unexpected molecules generated in response to different plants and plant lines. A better understanding of the viral population structure will have many implications for resistance breeding, irrespectively of whether a conventional method or genetic engineering is used. It is important to note that viruses may be regarded as highly polyploid entities. An error-prone lifestyle is, therefore, not only possible because wild type $(\mathrm{wt})$ versions can complement mutants in a cell, but it is also advantageous for the viral evolution, because a reservoir of potential survivors for changing environments is created before it is needed. Following this basic concept, begomoviruses (Euphorbia yellow mosaic virus, EuYMV; Cleome leaf crumple virus, ClLCrV) and their aSats were investigated in various T-DNA insertion lines of Arabidopsis thaliana to determine the shifts in the population structure and the influence of single host genes on the replication of the virus $[108,178-180,186]$. Biolistic inoculation of RCA products proved to be more efficient than agroinfectious clones in this case, and avoided a contribution of mutations within the bacteria. The changing viral DNA populations were determined by Illumina sequencing, and the technical error rates were checked with plasmid controls spiked into the samples. With these precautions, high substitution rates were regularly determined. Some variations were observed in different genetic plant lines, e.g., when a factor for non-homologous end-joining (KU80) retarded geminiviral multiplication [178], or when the homologous recombination mediator RAD51D promoted the geminiviral infection [186]. The role of error-prone translesion DNA synthesis in early viral replication inside phloem cells has been investigated [180]. Typically, high substitution rates of $10^{-4}$ to $10^{-3}$ were noticed in all these data sets, with preferences for deamination and oxidative changes of the nucleobases. In addition, high levels of D-DNAs were detected which had been overlooked before, since they form a heterogeneous population not represented in discrete bands in the RFLP analyses, but in background smears only. Raising elevated levels of DI-DNAs may be important as a means for cross-protection. However, D-DNAs may have ambivalent effects on symptoms and viral multiplication $[54,105]$, as shown for beet curly top virus (BCTV). This allowed for the conclusion that it is more appropriate to employ the whole viral DNA pool to experimentally challenge a resistance 
trait, than to use a single infectious clone with unknown relevance for the field situation. Moreover, RCA technology makes it possible to follow the changes in the population structure when new cultivars and environmental conditions are applied, to establish sustainable plant protection.

\section{Outlook}

In spite of some progress in engineering resistance in plants against geminiviruses and nanoviruses, quarantine measures, including early detection of invading viruses, are still the method of choice to combat epidemics worldwide. Educational training of farmers and plant protection staff to enable early eradication remains the key remedy. The RCA technology described here is simple and can be applied cost-effectively, in particular for tropical and subtropical countries with low budgets. Although commercial kits may be still too expensive for many applications in agriculture in these countries, an alternative exists, since the core enzyme, the Phi29 DNA polymerase, can be easily expressed in E. coli as a fusion protein [195]. For more sophisticated analyses, the growing treasure of databases allows immediate recognition of newly invading viruses. Improvements and economization of sequencing technology (in particular of single molecules) in central laboratories will expand the applicability of this diagnostic technology. A debate on the usage of the expanding knowledge has been raised, following the negotiations of the Nagoya protocol. Since the problem raised by geminiviruses and nanoviruses is a global one, rather than restricted to individual nations, an open access policy for fundamental research would be a wise option [196].

Supplementary Materials: The following are available online at http:/ /www.mdpi.com/1999-4915/10/9/469/s1. Figure S1: Statistics of the restriction enzyme recognition sequences as described in Figure 3 for the whole data set. Figure S2: Statistics of the restriction enzyme recognition sequences as described in Figure 4 for the whole data set. Table S1: Literature survey, 2004-2018. Table S2: Worksheet to calculate fragment sizes in relation to migration distances after gel electrophoresis.

Funding: This research received no external funding.

Acknowledgments: The critical comments and discussions of Christina Wege during the preparation of this manuscript are greatly appreciated. The list of collaborators, students, technicians, and gardeners, as well as of the participants of two international summer schools over the past decade, who contributed to the optimization of the RCA technology, would be too long for this paragraph, and are acknowledged here collectively and in the reference list in detail.

Conflicts of Interest: The author declares no conflict of interest.

\section{References}

1. Saunders, K.; Bedford, I.D.; Yahara, T.; Stanley, J. Aetiology: The earliest recorded plant virus disease. Nature 2003, 422, 831. [CrossRef] [PubMed]

2. Fischer, A.; Strohmeier, S.; Krenz, B.; Jeske, H. Evolutionary liberties of the Abutilon mosaic virus cluster. Virus Genes 2015, 50, 63-70. [CrossRef] [PubMed]

3. Wege, C.; Gotthardt, R.D.; Frischmuth, T.; Jeske, H. Fulfilling Koch's postulates for Abutilon mosaic virus. Arch. Virol. 2000, 145, 2217-2225. [CrossRef] [PubMed]

4. Moffat, A. Geminiviruses emerge as serious crop threat. Science 1999, 286, 1835. [CrossRef]

5. Rosas-Diaz, T.; Zhang, D.; Lozano-Duran, R. No evidence of seed transmissibility of Tomato yellow leaf curl virus in Nicotiana benthamiana. J. Zhejiang Univ. Sci. B 2017, 18, 437-440. [CrossRef] [PubMed]

6. Kil, E.J.; Kim, S.; Lee, Y.J.; Byun, H.S.; Park, J.; Seo, H.; Kim, C.S.; Shim, J.K.; Lee, J.H.; Kim, J.K.; et al. Tomato yellow leaf curl virus (TYLCV-Il): A seed-transmissible geminivirus in tomatoes. Sci. Rep. 2016, 6, 19013. [CrossRef] [PubMed]

7. Anabestani, A.; Behjatnia, S.A.A.; Izadpanah, K.; Tabein, S.; Accotto, G.P. Seed transmission of beet curly top virus and beet curly top iran virus in a local cultivar of petunia in Iran. Viruses 2017, 9, 299. [CrossRef] [PubMed]

8. Pooggin, M.M. How can plant DNA viruses evade siRNA-directed DNA methylation and silencing? Int. J. Mol. Sci. 2013, 14, 15233-15259. [CrossRef] [PubMed] 
9. Hanley-Bowdoin, L.; Bejarano, E.R.; Robertson, D.; Mansoor, S. Geminiviruses: Masters at redirecting and reprogramming plant processes. Nat. Rev. Microbiol. 2013, 11, 777-788. [CrossRef] [PubMed]

10. Jeske, H. Geminiviruses. In Torque Teno Virus: The Still Elusive Human Pathogens; zur Hausen, H., de Villiers, E.-M., Eds.; Springer: Berlin, Germany, 2009; Volume 331, pp. 185-226.

11. Briddon, R.W.; Stanley, J. Subviral agents associated with plant single-stranded DNA viruses. Virology 2006, 344, 198-210. [CrossRef] [PubMed]

12. Hassan, I.; Orilio, A.F.; Fiallo-Olive, E.; Briddon, R.W.; Navas-Castillo, J. Infectivity, effects on helper viruses and whitefly transmission of the deltasatellites associated with sweepoviruses (genus Begomovirus, family Geminiviridae). Sci. Rep. 2016, 6, 30204. [CrossRef] [PubMed]

13. Fiallo-Olive, E.; Tovar, R.; Navas-Castillo, J. Deciphering the biology of deltasatellites from the New World: Maintenance by New World begomoviruses and whitefly transmission. New Phytol. 2016, 212, 680-692. [CrossRef] [PubMed]

14. Lozano, G.; Trenado, H.P.; Fiallo-Olive, E.; Chirinos, D.; Geraud-Pouey, F.; Briddon, R.W.; Navas-Castillo, J. Characterization of non-coding DNA satellites associated with sweepoviruses (genus Begomovirus, Geminiviridae)—Definition of a distinct class of begomovirus-associated satellites. Front. Microbiol. 2016, 7, 162. [CrossRef] [PubMed]

15. Zhou, X. Advances in understanding begomovirus satellites. Annu. Rev. Phytopathol. 2013, 51, 357-381. [CrossRef] [PubMed]

16. Zerbini, F.M.; Briddon, R.W.; Idris, A.; Martin, D.P.; Moriones, E.; Navas-Castillo, J.; Rivera-Bustamante, R.; Roumagnac, P.; Varsani, A.; Ictv Report, C. ICTV virus taxonomy profile: Geminiviridae. J. Gen. Virol. 2017, 98, 131-133. [CrossRef] [PubMed]

17. Briddon, R.W.; Martin, D.P.; Roumagnac, P.; Navas-Castillo, J.; Fiallo-Olive, E.; Moriones, E.; Lett, J.M.; Zerbini, F.M.; Varsani, A. Alphasatellitidae: A new family with two subfamilies for the classification of geminivirus- and nanovirus-associated alphasatellites. Arch. Virol. 2018, 163, 2587-2600. [CrossRef] [PubMed]

18. Inoue-Nagata, A.K.; Albuquerque, L.C.; Rocha, W.B.; Nagata, T. A simple method for cloning the complete begomovirus genome using the bacteriophage phi 29 DNA polymerase. J. Virol. Methods 2004, 116, $209-211$. [CrossRef] [PubMed]

19. Haible, D.; Kober, S.; Jeske, H. Rolling circle amplification revolutionizes diagnosis and genomics of geminiviruses. J. Virol. Methods 2006, 135, 9-16. [CrossRef] [PubMed]

20. Schubert, J.; Habekuss, A.; Kazmaier, K.; Jeske, H. Surveying cereal-infecting geminiviruses in Germany-Diagnostics and direct sequencing using rolling circle amplification. Virus Res. 2007, 127, 61-70. [CrossRef] [PubMed]

21. Knierim, D.; Maiss, E. Application of phi29 DNA polymerase in identification and full-length clone inoculation of tomato yellow leaf curl Thailand virus and tobacco leaf curl Thailand virus. Arch. Virol. 2007, 152, 941-954. [CrossRef] [PubMed]

22. Owor, B.E.; Shepherd, D.N.; Taylor, N.J.; Edema, R.; Monjane, A.L.; Thomson, J.A.; Martin, D.P.; Varsani, A. Successful application of FTA classic card technology and use of bacteriophage phi 29 DNA polymerase for large-scale field sampling and cloning of complete maize streak virus genomes. J. Virol. Methods 2007, 140, 100-105. [CrossRef] [PubMed]

23. Kumar, Y.; Hallan, V.; Zaidi, A.A. Molecular characterization of a distinct bipartite begomovirus species infecting tomato in India. Virus Genes 2008, 37, 425-431. [CrossRef] [PubMed]

24. Homs, M.; Kober, S.; Kepp, G.; Jeske, H. Mitochondrial plasmids of sugar beet amplified via rolling circle method detected during curtovirus screening. Virus Res. 2008, 136, 124-129. [CrossRef] [PubMed]

25. Nahid, N.; Amin, I.; Mansoor, S.; Rybicki, E.P.; van der Walt, E.; Briddon, R.W. Two dicot-infecting mastreviruses (family Geminiviridae) occur in Pakistan. Arch. Virol. 2008, 153, 1441-1451. [CrossRef] [PubMed]

26. Shepherd, D.N.; Martin, D.P.; Lefeuvre, P.; Monjane, A.L.; Owor, B.E.; Rybicki, E.P.; Varsani, A. A protocol for the rapid isolation of full geminivirus genomes from dried plant tissue. J. Virol. Methods 2008, 149, 97-102. [CrossRef] [PubMed]

27. Wu, C.Y.; Lai, Y.C.; Lin, N.S.; Hsu, Y.H.; Tsai, H.T.; Liao, J.Y.; Hu, C.C. A simplified method of constructing infectious clones of begomovirus employing limited restriction enzyme digestion of products of rolling circle amplification. J. Virol. Methods 2008, 147, 355-359. [CrossRef] [PubMed] 
28. De Oliveira Ferreira, P.D.T.; Lemos, T.O.; Nagata, T.; Inoue-Nagata, A.K. One-step cloning approach for construction of agroinfectious begomovirus clones. J. Virol. Methods 2008, 147, 351-354. [CrossRef] [PubMed]

29. Ramsell, J.N.E.; Boulton, M.I.; Martin, D.P.; Valkonen, J.P.T.; Kvarnheden, A. Studies on the host range of the barley strain of wheat dwarf virus using an agroinfectious viral clone. Plant Pathol. 2009, 58, 1161-1169. [CrossRef]

30. Grigoras, I.; Timchenko, T.; Katul, L.; Grande-Perez, A.; Vetten, H.J.; Gronenborn, B. Reconstitution of authentic nanovirus from multiple cloned DNAs. J. Virol. 2009, 83, 10778-10787. [CrossRef] [PubMed]

31. Rosario, K.; Duffy, S.; Breitbart, M. Diverse circovirus-like genome architectures revealed by environmental metagenomics. J. Gen. Virol. 2009, 90, 2418-2424. [CrossRef] [PubMed]

32. Fernandes, F.R.; Cruz, A.R.R.; Faria, J.C.; Zerbini, F.M.; Aragao, F.J.L. Three distinct begomoviruses associated with soybean in Central Brazil. Arch. Virol. 2009, 154, 1567-1570. [CrossRef] [PubMed]

33. Kleinow, T.; Nischang, M.; Beck, A.; Kratzer, U.; Tanwir, F.; Preiss, W.; Kepp, G.; Jeske, H. Three C-terminal phosphorylation sites in the Abutilon mosaic virus movement protein affect symptom development and viral DNA accumulation. Virology 2009, 390, 89-101. [CrossRef] [PubMed]

34. Kumar, Y.; Bhardwaj, P.; Hallan, V.; Zaidi, A.A. Detection and characterization of Ageratum enation virus and a nanovirus-like satellite DNA1 from Zinnia causing leaf curl symptoms in India. J. Gen. Plant Pathol. 2010, 76, 395-398. [CrossRef]

35. Pandey, P.; Mukhopadhya, S.; Naqvi, A.R.; Mukherjee, S.K.; Shekhawat, G.S.; Choudhury, N.R. Molecular characterization of two distinct monopartite begomoviruses infecting tomato in India. Virol. J. 2010, 7. [CrossRef] [PubMed]

36. Krenz, B.; Wege, C.; Jeske, H. Cell-free construction of disarmed Abutilon mosaic virus-based gene silencing vectors. J. Virol. Methods 2010, 169, 129-137. [CrossRef] [PubMed]

37. Briddon, R.W.; Heydarnejad, J.; Khosrowfar, F.; Massumi, H.; Martin, D.P.; Varsani, A. Turnip curly top virus, a highly divergent geminivirus infecting turnip in Iran. Virus Res. 2010, 152, 169-175. [CrossRef] [PubMed]

38. Paprotka, T.; Metzler, V.; Jeske, H. The first DNA 1-like alpha satellites in association with New World begomoviruses in natural infections. Virology 2010, 404, 148-157. [CrossRef] [PubMed]

39. Guenoune-Gelbart, D.; Sufrin-Ringwald, T.; Capobianco, H.; Gaba, V.; Polston, J.E.; Lapidot, M. Inoculation of plants with begomoviruses by particle bombardment without cloning: Using rolling circle amplification of total DNA from infected plants and whiteflies. J. Virol. Methods 2010, 168, 87-93. [CrossRef] [PubMed]

40. Tiwari, N.; Padmalatha, K.V.; Singh, V.B.; Haq, Q.M.I.; Malathi, V.G. Tomato leaf curl Bangalore virus (ToLCBV): Infectivity and enhanced pathogenicity with diverse betasatellites. Arch. Virol. 2010, 155, 1343-1347. [CrossRef] [PubMed]

41. Packialakshmi, R.M.; Srivastava, N.; Girish, K.R.; Usha, R. Molecular characterization of a distinct begomovirus species from Vernonia cinerea and its associated DNA-beta using the bacteriophage Phi 29 DNA polymerase. Virus Genes 2010, 41, 135-143. [CrossRef] [PubMed]

42. Paprotka, T.; Metzler, V.; Jeske, H. The complete nucleotide sequence of a new bipartite begomovirus from Brazil infecting Abutilon. Arch. Virol. 2010, 155, 813-816. [CrossRef] [PubMed]

43. Paprotka, T.; Boiteux, L.S.; Fonseca, M.E.N.; Resende, R.O.; Jeske, H.; Faria, J.C.; Ribeiro, S.G. Genomic diversity of sweet potato geminiviruses in a Brazilian germplasm bank. Virus Res. 2010, 149, $224-233$. [CrossRef] [PubMed]

44. Kumar, A.; Kumar, J.; Khan, J.A. Sequence characterization of cotton leaf curl virus from Rajasthan: Phylogenetic relationship with other members of geminiviruses and detection of recombination. Virus Genes 2010, 40, 282-289. [CrossRef] [PubMed]

45. Tobias, I.; Kiss, B.; Salanki, K.; Palkovics, L. The nucleotide sequence of barley strain of Wheat dwarf virus isolated in hungary. Cereal Res. Commun. 2010, 38, 67-74. [CrossRef]

46. Van Brunschot, S.L.; Persley, D.M.; Geering, A.D.W.; Campbell, P.R.; Thomas, J.E. Tomato yellow leaf curl virus in Australia: Distribution, detection and discovery of naturally occurring defective DNA molecules. Australas. Plant Pathol. 2010, 39, 412-423. [CrossRef]

47. Blinkova, O.; Victoria, J.; Li, Y.Y.; Keele, B.F.; Sanz, C.; Ndjango, J.B.N.; Peeters, M.; Travis, D.; Lonsdorf, E.V.; Wilson, M.L.; et al. Novel circular DNA viruses in stool samples of wild-living chimpanzees. J. Gen. Virol. 2010, 91, 74-86. [CrossRef] [PubMed] 
48. Snehi, S.K.; Raj, S.K.; Khan, M.S.; Prasad, V. Molecular identification of a new begomovirus associated with yellow mosaic disease of Jatropha gossypifolia in India. Arch. Virol. 2011, 156, 2303-2307. [CrossRef] [PubMed]

49. Packialakshmi, R.M.; Usha, R. A simple and efficient method for agroinfection of Vernonia cinerea with infectious clones of Vernonia yellow vein virus. Virus Genes 2011, 43, 465-470. [CrossRef] [PubMed]

50. Paprotka, T.; Deuschle, K.; Metzler, V.; Jeske, H. Conformation-selective methylation of geminivirus DNA. J. Virol. 2011, 85, 12001-12012. [CrossRef] [PubMed]

51. Krenz, B.; Neugart, F.; Kleinow, T.; Jeske, H. Self-interaction of Abutilon mosaic virus replication initiator protein (rep) in plant cell nuclei. Virus Res. 2011, 161, 194-197. [CrossRef] [PubMed]

52. Park, J.; Lee, H.; Kim, M.K.; Kwak, H.R.; Auh, C.K.; Lee, K.Y.; Kim, S.; Choi, H.S.; Lee, S. Phylogenetic lineage of tobacco leaf curl virus in Korea and estimation of recombination events implicated in their sequence variation. Virus Res. 2011, 159, 124-131. [CrossRef] [PubMed]

53. Zaim, M.; Kumar, Y.; Hallan, V.; Zaidi, A.A. Velvet bean severe mosaic virus: A distinct begomovirus species causing severe mosaic in Mucuna pruriens (L.) dc. Virus Genes 2011, 43, 138-146. [CrossRef] [PubMed]

54. Horn, J.; Lauster, S.; Krenz, B.; Kraus, J.; Frischmuth, T.; Jeske, H. Ambivalent effects of defective DNA in beet curly top virus-infected transgenic sugarbeet plants. Virus Res. 2011, 158, 169-178. [CrossRef] [PubMed]

55. Zhang, S.C.; Ling, K.S. Genetic diversity of sweet potato begomoviruses in the United States and identification of a natural recombinant between sweet potato leaf curl virus and sweet potato leaf curl Georgia virus. Arch. Virol. 2011, 156, 955-968. [CrossRef] [PubMed]

56. Kumar, Y.; Hallan, V.; Zaidi, A.A. First report of Ageratum enation virus infecting Crassocephalum crepidioides (Benth.) s. Moore and Ageratum conyzoides L. In india. J. Gen. Plant Pathol. 2011, 77, 214-216. [CrossRef]

57. Wyant, P.S.; Gotthardt, D.; Schafer, B.; Krenz, B.; Jeske, H. The genomes of four novel begomoviruses and a new Sida micrantha mosaic virus strain from Bolivian weeds. Arch. Virol. 2011, 156, 347-352. [CrossRef] [PubMed]

58. Tobias, I.; Shevchenko, O.; Kiss, B.; Bysov, A.; Snihur, H.; Polischuk, V.; Salanki, K.; Palkovics, L. Comparison of the nucleotide sequences of wheat dwarf virus (WDV) isolates from Hungary and Ukraine. Pol. J. Microbiol. 2011, 60, 125-131. [PubMed]

59. Aranha, S.D.; de Albuquerque, L.C.; Boiteux, L.S.; Inoue-Nagata, A.K. Detection and complete genome characterization of a begomovirus infecting okra (Abelmoschus esculentus) in Brazil. Trop. Plant Pathol. 2011, 36, 14-20. [CrossRef]

60. Marquez-Martin, B.; Aragon-Caballero, L.; Fiallo-Olive, E.; Navas-Castillo, J.; Moriones, E. Tomato leaf deformation virus, a novel begomovirus associated with a severe disease of tomato in Peru. Eur. J. Plant Pathol. 2011, 129, 1-7. [CrossRef]

61. Snehi, S.K.; Srivastava, A.; Raj, S.K. Biological characterization and complete genome sequence of a possible strain of Indian cassava mosaic virus from Jatropha curcas in India. J. Phytopathol. 2012, 160, 547-553. [CrossRef]

62. Rocha, K.C.G.; Marubayashi, J.M.; Mituti, T.; Gioria, R.; Kobori, R.F.; Melo, A.M.T.; Pavan, M.A.; Krause-Sakate, R. Evaluation of resistance to tomato severe rugose virus (ToSRV) in Capsicum spp. genotypes. Trop. Plant Pathol. 2012, 37, 314-318. [CrossRef]

63. Tavares, S.S.; Ramos-Sobrinho, R.; Gonzalez-Aguilera, J.; Lima, G.S.A.; Assuncao, I.P.; Zerbini, F.M. Further molecular characterization of weed-associated begomoviruses in Brazil with an emphasis on Sida spp. Planta Daninha 2012, 30, 305-315. [CrossRef]

64. Rosario, K.; Dayaram, A.; Marinov, M.; Ware, J.; Kraberger, S.; Stainton, D.; Breitbart, M.; Varsani, A. Diverse circular ssDNA viruses discovered in dragonflies (Odonata: Epiprocta). J. Gen. Virol. 2012, 93, 2668-2681. [CrossRef] [PubMed]

65. Idris, A.M.; Abdullah, N.M.; Brown, J.K. Leaf curl diseases of two solanaceous species in Southwest Arabia are caused by a monopartite begomovirus evolutionarily most closely related to a species from the nile basin and unique suite of betasatellites. Virus Res. 2012, 169, 296-300. [CrossRef] [PubMed]

66. Kumar, J.; Singh, S.P.; Kumar, J.; Tuli, R. A novel mastrevirus infecting wheat in India. Arch. Virol. 2012, 157, 2031-2034. [CrossRef] [PubMed]

67. Nawaz-Ul-Rehman, M.S.; Briddon, R.W.; Fauquet, C.M. A melting pot of Old World begomoviruses and their satellites infecting a collection of Gossypium species in Pakistan. PLoS ONE 2012, 7. [CrossRef] [PubMed] 
68. Wyant, P.S.; Kober, S.; Schwierzok, A.; Kocher, C.; Schafer, B.; Jeske, H.; Wege, C. Cloned tomato golden mosaic virus back in tomatoes. Virus Res. 2012, 167, 397-403. [CrossRef] [PubMed]

69. Whon, T.W.; Kim, M.S.; Roh, S.W.; Shin, N.R.; Lee, H.W.; Bae, J.W. Metagenomic characterization of airborne viral DNA diversity in the near-surface atmosphere. J. Virol. 2012, 86, 8221-8231. [CrossRef] [PubMed]

70. Matic, S.; da Cunha, A.T.P.; Thompson, J.R.; Tepfer, M. An analysis of viruses associated with cassava mosaic disease in three Angolan provinces. J. Plant Pathol. 2012, 94, 443-450.

71. Valverde, R.A.; Singh, R.; Sabanadzovic, S. Detection and identification of Clerodendron golden mosaic china virus in Salvia splendens. Eur. J. Plant Pathol. 2012, 133, 499-503. [CrossRef]

72. Wyant, P.S.; Strohmeier, S.; Schafer, B.; Krenz, B.; Assuncao, I.P.; Lima, G.S.D.; Jeske, H. Circular DNA genomics (circomics) exemplified for geminiviruses in bean crops and weeds of Northeastern Brazil. Virology 2012, 427, 151-157. [CrossRef] [PubMed]

73. Dayaram, A.; Opong, A.; Jaschke, A.; Hadfield, J.; Baschiera, M.; Dobson, R.C.J.; Offei, S.K.; Shepherd, D.N.; Martin, D.P.; Varsani, A. Molecular characterisation of a novel cassava associated circular ssDNA virus. Virus Res. 2012, 166, 130-135. [CrossRef] [PubMed]

74. Silva, S.J.C.; Castillo-Urquiza, G.P.; Hora, B.T.; Assuncao, I.P.; Lima, G.S.A.; Pio-Ribeiro, G.; Mizubuti, E.S.G.; Zerbini, F.M. Species diversity, phylogeny and genetic variability of begomovirus populations infecting leguminous weeds in Northeastern Brazil. Plant Pathol. 2012, 61, 457-467. [CrossRef]

75. Zaffalon, V.; Mukherjee, S.K.; Reddy, V.S.; Thompson, J.R.; Tepfer, M. A survey of geminiviruses and associated satellite DNAs in the cotton-growing areas of Northwestern India. Arch. Virol. 2012, 157, 483-495. [CrossRef] [PubMed]

76. Delwart, E.; Li, L.L. Rapidly expanding genetic diversity and host range of the Circoviridae viral family and other rep encoding small circular ssDNA genomes. Virus Res. 2012, 164, 114-121. [CrossRef] [PubMed]

77. Oteng-Frimpong, R.; Levy, Y.; Torkpo, S.K.; Danquah, E.Y.; Offei, S.K.; Gafni, Y. Complete genome sequencing of two causative viruses of cassava mosaic disease in Ghana. Acta Virol. 2012, 56, 305-314. [CrossRef] [PubMed]

78. Kumar, J.; Gunapati, S.; Singh, S.P.; Gadre, R.; Sharma, N.C.; Tuli, R. Molecular characterization and pathogenicity of a carrot (Daucus carota) infecting begomovirus and associated betasatellite from India. Virus Res. 2013, 178, 478-485. [CrossRef] [PubMed]

79. Satya, V.K.; Malathi, V.G.; Velazhahan, R.; Rabindran, R.; Jayamani, P.; Alice, D. Characterization of betasatellite associated with the yellow mosaic disease of grain legumes in Southern India. Acta Virol. 2013, 57, 405-414. [CrossRef] [PubMed]

80. Srivastava, A.; Raj, S.K.; Kumar, S.; Snehi, S.K.; Kulshreshtha, A.; Hallan, V.; Pande, S.S. Molecular identification of Ageratum enation virus, betasatellite and alphasatellite molecules isolated from yellow vein diseased Amaranthus cruentus in India. Virus Genes 2013, 47, 584-590. [CrossRef] [PubMed]

81. Sikorski, A.; Massaro, M.; Kraberger, S.; Young, L.M.; Smalley, D.; Martin, D.P.; Varsani, A. Novel myco-like DNA viruses discovered in the faecal matter of various animals. Virus Res. 2013, 177, 209-216. [CrossRef] [PubMed]

82. Al Rwahnih, M.; Dave, A.; Anderson, M.M.; Rowhani, A.; Uyemoto, J.K.; Sudarshana, M.R. Association of a DNA virus with grapevines affected by red blotch disease in California. Phytopathology 2013, 103, 1069-1076. [CrossRef] [PubMed]

83. Bernardo, P.; Golden, M.; Akram, M.; Naimuddin; Nadarajan, N.; Fernandez, E.; Granier, M.; Rebelo, A.G.; Peterschmitt, M.; Martin, D.P.; et al. Identification and characterisation of a highly divergent geminivirus: Evolutionary and taxonomic implications. Virus Res. 2013, 177, 35-45. [CrossRef] [PubMed]

84. Jyothsna, P.; Haq, Q.M.I.; Jayaprakash, P.; Malathi, V.G. Molecular evidence for the occurrence of Abutilon mosaic virus, a New World begomovirus in India. Indian J. Virol. 2013, 24, 284-288. [CrossRef] [PubMed]

85. Geetanjali, A.S.; Shilpi, S.; Mandal, B. Natural association of two different betasatellites with sweet potato leaf curl virus in wild morning glory (Ipomoea purpurea) in India. Virus Genes 2013, 47, 184-188. [CrossRef] [PubMed]

86. Roy, A.; Spoorthi, P.; Bag, M.K.; Prasad, T.V.; Singh, R.; Dutta, M.; Mandal, B. A leaf curl disease in germplasm of rapeseed-mustard in India: Molecular evidence of a weed-infecting begomovirus-betasatellite complex emerging in a new crop. J. Phytopathol. 2013, 161, 522-535. [CrossRef]

87. Kardani, S.G.; Heydarnejad, J.; Zakiaghl, M.; Mehrvar, M.; Kraberger, S.; Varsani, A. Diversity of beet curly top Iran virus isolated from different hosts in Iran. Virus Genes 2013, 46, 571-575. [CrossRef] [PubMed] 
88. Roy, A.; Spoorthi, P.; Panwar, G.; Bag, M.K.; Prasad, T.V.; Kumar, G.; Gangopadhyay, K.K.; Dutta, M. Molecular evidence for occurrence of tomato leaf curl New Delhi virus in ash gourd (Benincasa hispida) germplasm showing a severe yellow stunt disease in India. Indian J. Virol. 2013, 24, 74-77. [CrossRef] [PubMed]

89. Pramesh, D.; Mandal, B.; Phaneendra, C.; Muniyappa, V. Host range and genetic diversity of croton yellow vein mosaic virus, a weed-infecting monopartite begomovirus causing leaf curl disease in tomato. Arch. Virol. 2013, 158, 531-542. [CrossRef] [PubMed]

90. Kamaal, N.; Akram, M.; Pratap, A.; Yadav, P. Characterization of a new begomovirus and a beta satellite associated with the leaf curl disease of french bean in Northern India. Virus Genes 2013, 46, 120-127. [CrossRef] [PubMed]

91. Coco, D.; Calil, I.P.; Brustolini, O.J.B.; Santos, A.A.; Inoue-Nagata, A.K.; Fontes, E.P.B. Soybean chlorotic spot virus, a novel begomovirus infecting soybean in Brazil. Arch. Virol. 2013, 158, 457-462. [CrossRef] [PubMed]

92. Kanakala, S.; Sakhare, A.; Verma, H.N.; Malathi, V.G. Infectivity and the phylogenetic relationship of a mastrevirus causing chickpea stunt disease in India. Eur. J. Plant Pathol. 2013, 135, 429-438. [CrossRef]

93. Tiwari, N.; Singh, V.B.; Sharma, P.K.; Malathi, V.G. Tomato leaf curl joydebpur virus: A monopartite begomovirus causing severe leaf curl in tomato in West Bengal. Arch. Virol. 2013, 158, 1-10. [CrossRef] [PubMed]

94. Ali-Shtayeh, M.S.; Jamous, R.M.; Hussein, E.Y.; Mallah, O.B.; Abu-Zeitoun, S.Y. Squash leaf curl virus (SLCV): A serious disease threatening cucurbits production in Palestine. Virus Genes 2014, 48, 320-328. [CrossRef] [PubMed]

95. Just, K.; Leke, W.N.; Sattar, M.N.; Luik, A.; Kvarnheden, A. Detection of tomato yellow leaf curl virus in imported tomato fruit in Northern Europe. Plant Pathol. 2014, 63, 1454-1460. [CrossRef]

96. Jeske, H.; Kober, S.; Schafer, B.; Strohmeier, S. Circomics of Cuban geminiviruses reveals the first alpha-satellite DNA in the Caribbean. Virus Genes 2014, 49, 312-324. [CrossRef] [PubMed]

97. Bang, B.; Lee, J.; Kim, S.; Park, J.; Nguyen, T.T.; Seo, Y.S. A rapid and efficient method for construction of an infectious clone of tomato yellow leaf curl virus. Plant Pathol. J. 2014, 30, 310-315. [CrossRef] [PubMed]

98. Kil, E.J.; Byun, H.S.; Kim, S.; Kim, J.; Park, J.; Cho, S.; Yang, D.C.; Lee, K.Y.; Choi, H.S.; Kim, J.K.; et al. Sweet pepper confirmed as a reservoir host for tomato yellow leaf curl virus by both agro-inoculation and whitefly-mediated inoculation. Arch. Virol. 2014, 159, 2387-2395. [CrossRef] [PubMed]

99. Paz-Carrasco, L.C.; Castillo-Urquiza, G.P.; Lima, A.T.M.; Xavier, C.A.D.; Vivas-Vivas, L.M.; Mizubuti, E.S.G.; Zerbini, F.M. Begomovirus diversity in tomato crops and weeds in Ecuador and the detection of a recombinant isolate of Rhynchosia golden mosaic Yucatan virus infecting tomato. Arch. Virol. 2014, 159, 2127-2132. [CrossRef] [PubMed]

100. Khatri, S.; Nahid, N.; Fauquet, C.M.; Mubin, M.; Nawaz-ul-Rehman, M.S. A betasatellite-dependent begomovirus infects ornamental rose: Characterization of begomovirus infecting rose in Pakistan. Virus Genes 2014, 49, 124-131. [CrossRef] [PubMed]

101. Ullah, R.; Akhtar, K.P.; Moffett, P.; Mansoor, S.; Briddon, R.W.; Saeed, M. An analysis of the resistance of Gossypium arboreum to cotton leaf curl disease by grafting. Eur. J. Plant Pathol. 2014, 139, 837-847. [CrossRef]

102. Srivastava, A.; Kumar, S.; Raj, S.K. Association of Pedilanthus leaf curl virus with yellow mottling and leaf curl symptoms in two jasmine species grown in India. J. Gen. Plant Pathol. 2014, 80, 370-373. [CrossRef]

103. Ali-Shtayeh, M.S.; Jamous, R.M.; Mallah, O.B.; Abu-Zeitoun, S.Y. Molecular characterization of watermelon chlorotic stunt virus (WmCSV) from Palestine. Viruses 2014, 6, 2444-2462. [CrossRef] [PubMed]

104. Dugdale, B.; Mortimer, C.L.; Kato, M.; James, T.A.; Harding, R.M.; Dale, J.L. Design and construction of an in-plant activation cassette for transgene expression and recombinant protein production in plants. Nat. Protoc. 2014, 9, 1010-1027. [CrossRef] [PubMed]

105. Bach, J.; Jeske, H. Defective DNAs of beet curly top virus from long-term survivor sugar beet plants. Virus Res. 2014, 183, 89-94. [CrossRef] [PubMed]

106. Silva, F.N.; Lima, A.T.M.; Rocha, C.S.; Castillo-Urquiza, G.P.; Alves, M.; Zerbini, F.M. Recombination and pseudorecombination driving the evolution of the begomoviruses tomato severe rugose virus (ToSRV) and tomato rugose mosaic virus (ToRMV): Two recombinant DNA-A components sharing the same DNA-B. Virol. J. 2014, 11, 66. [CrossRef] [PubMed]

107. Idris, A.; Al-Saleh, M.; Piatek, M.J.; Al-Shahwan, I.; Ali, S.; Brown, J.K. Viral metagenomics: Analysis of begomoviruses by illumina high-throughput sequencing. Viruses 2014, 6, 1219-1236. [CrossRef] [PubMed] 
108. Richter, K.S.; Kleinow, T.; Jeske, H. Somatic homologous recombination in plants is promoted by a geminivirus in a tissue-selective manner. Virology 2014, 452, 287-296. [CrossRef] [PubMed]

109. Yang, X.L.; Zhou, M.N.; Qian, Y.J.; Xie, Y.; Zhou, X.P. Molecular variability and evolution of a natural population of tomato yellow leaf curl virus in Shanghai, China. J. Zhejiang Univ.-Sci. B 2014, 15, 133-142. [CrossRef] [PubMed]

110. Nehra, C.; Gaur, R.K. Molecular characterization of chilli leaf curl viruses infecting new host plant Petunia hybrida in India. Virus Genes 2015, 50, 58-62. [CrossRef] [PubMed]

111. Srivastava, A.; Jaidi, M.; Kumar, S.; Raj, S.K. Molecular identification of a new begomovirus associated with leaf crumple disease of Jatropha curcas L. in India. Arch. Virol. 2015, 160, 617-619. [CrossRef] [PubMed]

112. Chen, S.; Huang, Q.Q.; Wu, L.Q.; Qian, Y.J. Identification and characterization of a maize-associated mastrevirus in China by deep sequencing small RNA populations. Virol. J. 2015, 12, 156. [CrossRef] [PubMed]

113. Ammara, U.E.; Al-Ansari, M.; Al-Shihi, A.; Amin, I.; Mansoor, S.; Al-Maskari, A.Y.; Al-Sadi, A.M. Association of three begomoviruses and a betasatellite with leaf curl disease of basil in Oman. Can. J. Plant Pathol. 2015, 37, 506-513. [CrossRef]

114. Rishishwar, R.; Mazumdar, B.; Dasgupta, I. Diverse and recombinant begomoviruses and various satellites are associated with bhendi yellow vein mosaic disease of okra in India. J. Plant Biochem. Biot. 2015, 24, 470-475. [CrossRef]

115. Liang, P.B.; Navarro, B.; Zhang, Z.X.; Wang, H.Q.; Lu, M.G.; Xiao, H.; Wu, Q.F.; Zhou, X.P.; Di Serio, F.; Li, S.F. Identification and characterization of a novel geminivirus with a monopartite genome infecting apple trees. J. Gen. Virol. 2015, 96, 2411-2420. [CrossRef] [PubMed]

116. Ma, Y.X.; Navarro, B.; Zhang, Z.X.; Lu, M.G.; Zhou, X.P.; Chi, S.Q.; Di Serio, F.; Li, S.F. Identification and molecular characterization of a novel monopartite geminivirus associated with mulberry mosaic dwarf disease. J. Gen. Virol. 2015, 96, 2421-2434. [CrossRef] [PubMed]

117. Sudarshana, M.R.; Perry, K.L.; Fuchs, M.F. Grapevine red blotch-associated virus, an emerging threat to the grapevine industry. Phytopathology 2015, 105, 1026-1032. [CrossRef] [PubMed]

118. Sharma, S.K.; Kumar, P.V.; Geetanjali, A.S.; Pun, K.B.; Baranwal, V.K. Subpopulation level variation of banana streak viruses in India and common evolution of banana and sugarcane badnaviruses. Virus Genes 2015, 50, 450-465. [CrossRef] [PubMed]

119. Herrera, F.; Aboughanem-Sabanadzovic, N.; Valverde, R.A. A begomovirus associated with yellow vein symptoms of Oxalis debilis. Eur. J. Plant Pathol. 2015, 142, 203-208. [CrossRef]

120. Srivastava, A.; Kumar, S.; Jaidi, M.; Raj, S.K. Characterization of a novel begomovirus associated with yellow mosaic disease of three ornamental species of Jatropha grown in India. Virus Res. 2015, 201, 41-49. [CrossRef] [PubMed]

121. Sahu, A.K.; Nehra, C.; Marwal, A.; Gaur, R.K. First report of a begomovirus associated with betasatellites infecting spinach (Spinacia oleracea) in India. J. Gen. Plant Pathol. 2015, 81, 146-150. [CrossRef]

122. Ullah, R.; Akhtar, K.P.; Hassan, I.; Saeed, M.; Sarwar, N.; Mansoor, S. Evidence of cotton leaf curl Burewala virus variant and its associate betasatellite causing yellow mosaic of eggplant (Solanum melongena) in Pakistan. J. Phytopathol. 2015, 163, 233-237. [CrossRef]

123. Srivastava, A.; Jaidi, M.; Kumar, S.; Raj, S.K.; Shukla, S. Association of papaya leaf curl virus with the leaf curl disease of grain amaranth (Amaranthus cruentus L.) in India. Phytoparasitica 2015, 43, 97-101. [CrossRef]

124. Wyant, P.; Strohmeier, S.; Fischer, A.; Schafer, B.; Briddon, R.W.; Krenz, B.; Jeske, H. Light-dependent segregation of begomoviruses in Asystasia gangetica leaves. Virus Res. 2015, 195, 225-235. [CrossRef] [PubMed]

125. Kushawaha, A.K.; Rabindran, R.; Dasgupta, I. Phylogenetic analysis and biolistic infectivity of a cloned Sri Lankan cassava mosaic virus DNA-A from Tamil Nadu, India on Nicotiana benthamiana. Acta Virol. 2015, 59, 57-63. [CrossRef] [PubMed]

126. Shahid, M.S.; Ikegami, M.; Briddon, R.W.; Natsuaki, K.T. Characterization of tomato yellow leaf curl virus and associated alphasatellite infecting Cucurbita maxima in Japan. J. Gen. Plant Pathol. 2015, 81, 92-95. [CrossRef]

127. Leke, W.N.; Khatabi, B.; Mignouna, D.B.; Brown, J.K.; Fondong, V.N. Complete genome sequence of a new bipartite begomovirus infecting cotton in the republic of Benin in West Africa. Arch. Virol. 2016, 161, 2329-2333. [CrossRef] [PubMed] 
128. Deuschle, K.; Kepp, G.; Jeske, H. Differential methylation of the circular DNA in geminiviral minichromosomes. Virology 2016, 499, 243-258. [CrossRef] [PubMed]

129. Priyavathi, P.; Kavitha, V.; Gopal, P. Complex nature of infection associated with yellow vein mosaic disease in bhendi (Abelmoschus esculentus). Curr. Sci. India 2016, 111, 1511-1515. [CrossRef]

130. Kumar, S.; Srivastava, A.; Jaidi, M.; Chauhan, P.S.; Raj, S.K. Molecular characterization of a begomovirus, alpha-satellite, and beta-satellite associated with leaf curl disease of Parthenium hysterophorus in India. Plant Dis. 2016, 100, 2299-2305. [CrossRef]

131. Pearson, V.M.; Caudle, S.B.; Rokyta, D.R. Viral recombination blurs taxonomic lines: Examination of single-stranded DNA viruses in a wastewater treatment plant. Peerj 2016, 4, e2585. [CrossRef] [PubMed]

132. Sharma, S.; Singh, L.; Roshan, P.; Kulshreshtha, A.; Singh, N.; Hallan, V. Complete nucleotide sequence of Ageratum enation virus and an alphasatellite infecting a new host Glycine max in India. J. Phytopathol. 2016, 164, 554-557. [CrossRef]

133. Bernardo, P.; Muhire, B.; Francois, S.; Deshoux, M.; Hartnady, P.; Farkas, K.; Kraberger, S.; Filloux, D.; Fernandez, E.; Galzi, S.; et al. Molecular characterization and prevalence of two capulaviruses: Alfalfa leaf curl virus from France and Euphorbia caput-medusae latent virus from South Africa. Virology 2016, 493, 142-153. [CrossRef] [PubMed]

134. Kamali, M.; Heydarnejad, J.; Massumi, H.; Kvarnheden, A.; Kraberger, S.; Varsani, A. Molecular diversity of turncurtoviruses in Iran. Arch. Virol. 2016, 161, 551-561. [CrossRef] [PubMed]

135. Nagendran, K.; Satya, V.K.; Mohankumar, S.; Karthikeyan, G. Molecular characterization of a distinct bipartite begomovirus species infecting ivy gourd (Coccinia grandis L.) in Tamil Nadu, India. Virus Genes 2016, 52, 146-151. [CrossRef] [PubMed]

136. Naimuddin, K.; Akram, M.; Agnihotri, A.K. Molecular characterization of a first begomovirus associated with lentil (Lens culinaris) from India. Acta Virol. 2016, 60, 217-223. [CrossRef] [PubMed]

137. Akmal, M.; Baig, M.S.; Khan, J.A. Suppression of cotton leaf curl disease symptoms in Gossypium hirsutum through over expression of host-encoded miRnas. J. Biotechnol. 2017, 263, 21-29. [CrossRef] [PubMed]

138. Passos, L.S.; Rodrigues, J.S.; Soares, E.C.S.; Silva, J.P.; Zerbini, F.M.; Araujo, A.S.F.; Beserra, J.E.A. Complete genome sequence of a new bipartite begomovirus infecting Macroptilium lathyroides in Brazil. Arch. Virol. 2017, 162, 3551-3554. [CrossRef] [PubMed]

139. Silva, J.C.F.; Carvalho, T.F.M.; Fontes, E.P.B.; Cerqueira, F.R. Fangorn forest (f2): A machine learning approach to classify genes and genera in the family Geminiviridae. BMC Bioinform. 2017, 18, 431. [CrossRef] [PubMed]

140. Regnard, G.L.; de Moor, W.R.J.; Hitzeroth, I.I.; Williamson, A.L.; Rybicki, E.P. Xenogenic rolling-circle replication of a synthetic beak and feather disease virus genomic clone in 293tt mammalian cells and Nicotiana benthamiana. J. Gen. Virol. 2017, 98, 2329-2338. [CrossRef] [PubMed]

141. Tang, Y.F.; He, Z.F.; Brown, J.K.; She, X.M.; Lan, G.B. Molecular characterization of a novel bipartite begomovirus isolated from Lycianthes biflora in China. Arch. Virol. 2017, 162, 2473-2476. [CrossRef] [PubMed]

142. Boukari, W.; Alcala-Briseno, R.I.; Kraberger, S.; Fernandez, E.; Filloux, D.; Daugrois, J.H.; Comstock, J.C.; Lett, J.M.; Martin, D.P.; Varsani, A.; et al. Occurrence of a novel mastrevirus in sugarcane germplasm collections in Florida, Guadeloupe and Reunion. Virol. J. 2017, 14, 146. [CrossRef] [PubMed]

143. Carvajal-Yepes, M.; Zambrano, L.; Bueno, J.M.; Raatz, B.; Cuellar, W.J. Complete genome sequence of bean leaf crumple virus, a novel begomovirus infecting common bean in Colombia. Arch. Virol. 2017, 162, 1773-1776. [CrossRef] [PubMed]

144. Varsani, A.; Roumagnac, P.; Fuchs, M.; Navas-Castillo, J.; Moriones, E.; Idris, A.; Briddon, R.W.; Rivera-Bustamante, R.; Zerbini, F.M.; Martin, D.P. Capulavirus and Grablovirus: Two new genera in the family Geminiviridae. Arch. Virol. 2017, 162, 1819-1831. [CrossRef] [PubMed]

145. Silva, J.C.F.; Carvalho, T.F.M.; Basso, M.F.; Deguchi, M.; Pereira, W.A.; Sobrinho, R.R.; Vidigal, P.M.P.; Brustolini, O.J.B.; Silva, F.F.; Dal-Bianco, M.; et al. Geminivirus data warehouse: A database enriched with machine learning approaches. BMC Bioinform. 2017, 18, 240. [CrossRef] [PubMed]

146. Anwar, S. Distinct association of an alphasatellite and a betasatellite with tomato leaf curl New Delhi virus in field-infected cucurbit. J. Gen. Plant Pathol. 2017, 83, 185-188. [CrossRef]

147. Parizipour, M.H.G.; Schubert, J.; Behjatnia, S.A.A.; Afsharifar, A.; Habekuss, A.; Wu, B.L. Phylogenetic analysis of wheat dwarf virus isolates from Iran. Virus Genes 2017, 53, 266-274. [CrossRef] [PubMed] 
148. Mishra, G.P.; Singh, B.; Seth, T.; Singh, A.K.; Halder, J.; Krishnan, N.; Tiwari, S.K.; Singh, P.M. Biotechnological advancements and begomovirus management in okra (Abelmoschus esculentus L.): Status and perspectives. Front. Plant Sci. 2017, 8, 360. [CrossRef] [PubMed]

149. Ferro, C.G.; Silva, J.P.; Xavier, C.A.D.; Godinho, M.T.; Lima, A.T.M.; Mar, T.B.; Lau, D.; Zerbini, F.M. The ever increasing diversity of begomoviruses infecting non-cultivated hosts: New species from Sida spp. and Leonurus sibiricus, plus two new world alphasatellites. Ann. Appl. Biol. 2017, 170, 204-218. [CrossRef]

150. Shahid, M.S.; Briddon, R.W.; Al-Sadi, A.M. Identification of mungbean yellow mosaic Indian virus associated with tomato leaf curl betasatellite infecting Phaseolus vulgaris in Oman. J. Phytopathol. 2017, 165, 204-211. [CrossRef]

151. Just, K.; Sattar, M.N.; Arif, U.; Luik, A.; Kvarnheden, A. Infectivity of tomato yellow leaf curl virus isolated from imported tomato fruit in Estonia. Zemdirbyste 2017, 104, 47-52. [CrossRef]

152. Godara, S.; Khurana, S.M.P.; Biswas, K.K. Three variants of cotton leaf curl begomoviruses with their satellite molecules are associated with cotton leaf curl disease aggravation in New Delhi. J. Plant Biochem. Biot. 2017, 26, 97-105. [CrossRef]

153. Gronenborn, B.; Randles, J.W.; Knierim, D.; Barriere, Q.; Vetten, H.J.; Warthmann, N.; Cornu, D.; Sileye, T.; Winter, S.; Timchenko, T. Analysis of DNAs associated with coconut foliar decay disease implicates a unique single-stranded DNA virus representing a new taxon. Sci. Rep. 2018, 8, 5698. [CrossRef] [PubMed]

154. Heydarnejad, J.; Kamali, M.; Hassanvand, V.; Massumi, H.; Shamshiri, M.; Varsani, A. Turnip leaf curl disease associated with two begomoviruses in south-eastern Iran. Trop. Plant Pathol. 2018, 43, 165-169. [CrossRef]

155. Macedo, M.A.; Albuquerque, L.C.; Maliano, M.R.; Souza, J.O.; Rojas, M.R.; Inoue-Nagata, A.K.; Gilbertson, R.L. Characterization of tomato leaf curl purple vein virus, a new monopartite New World begomovirus infecting tomato in Northeast Brazil. Arch. Virol. 2018, 163, 737-743. [CrossRef] [PubMed]

156. Mendoza-Figueroa, J.S.; Kvarnheden, A.; Mendez-Lozano, J.; Rodriguez-Negrete, E.A.; de los Monteros, R.A.E.; Soriano-Garcia, M. A peptide derived from enzymatic digestion of globulins from amaranth shows strong affinity binding to the replication origin of tomato yellow leaf curl virus reducing viral replication in Nicotiana benthamiana. Pestic. Biochem. Phys. 2018, 145, 56-65. [CrossRef] [PubMed]

157. Kumar, A.; Bag, M.K.; Singh, R.; Jailani, A.A.K.; Mandal, B.; Roy, A. Natural infection of croton yellow vein mosaic virus and its cognate betasatellite in germplasm of different Crambe spp in India. Virus Res. 2018, 243, 60-64. [CrossRef] [PubMed]

158. Mulabisana, M.J.; Cloete, M.; Mabasa, K.G.; Laurie, S.M.; Oelofse, D.; Esterhuizen, L.L.; Rey, M.E.C. Surveys in the Gauteng, Limpopo and Mpumalanga provinces of South Africa reveal novel isolates of sweet potato viruses. S. Afr. J. Bot. 2018, 114, 280-294. [CrossRef]

159. Perry, K.L.; McLane, H.; Thompson, J.R.; Fuchs, M. A novel grablovirus from non-cultivated grapevine (Vitis sp.) in North America. Arch. Virol. 2018, 163, 259-262. [CrossRef] [PubMed]

160. Dominguez-Duran, G.; Rodriguez-Negrete, E.A.; Morales-Aguilar, J.J.; Camacho-Beltran, E.; Romero-Romero, J.L.; Rivera-Acosta, M.A.; Leyva-Lopez, N.E.; Arroyo-Becerra, A.; Mendez-Lozano, J. Molecular and biological characterization of watermelon chlorotic stunt virus (WmCSV): An eastern hemisphere begomovirus introduced in the western hemisphere. Crop Prot. 2018, 103, 51-55. [CrossRef]

161. Fondong, V.N. The search for resistance to cassava mosaic geminiviruses: How much we have accomplished, and what lies ahead. Front. Plant Sci. 2017, 8, 408. [CrossRef] [PubMed]

162. Blanc, S.; Gutierrez, S. The specifics of vector transmission of arboviruses of vertebrates and plants. Curr. Opin. Virol. 2015, 15, 27-33. [CrossRef] [PubMed]

163. Roumagnac, P.; Granier, M.; Bernardo, P.; Deshoux, M.; Ferdinand, R.; Galzi, S.; Fernandez, E.; Julian, C.; Abt, I.; Filloux, D.; et al. Alfalfa leaf curl virus: An aphid-transmitted geminivirus. J. Virol. 2015, 89, 9683-9688. [CrossRef] [PubMed]

164. Zubair, M.; Zaidi, S.S.; Shakir, S.; Amin, I.; Mansoor, S. An insight into cotton leaf curl multan betasatellite, the most important component of cotton leaf curl disease complex. Viruses 2017, 9, 280. [CrossRef] [PubMed]

165. Zaidi, S.S.; Mansoor, S. Viral vectors for plant genome engineering. Front. Plant Sci. 2017, 8, 539. [CrossRef] [PubMed]

166. Rybicki, E.P.; Martin, D.P. Virus-derived ssDNA vectors for the expression of foreign proteins in plants. Curr. Top. Microbiol. Immunol. 2014, 375, 19-45. [PubMed] 
167. Moriones, E.; Praveen, S.; Chakraborty, S. Tomato leaf curl New Delhi virus: An emerging virus complex threatening vegetable and fiber crops. Viruses 2017, 9, 264. [CrossRef] [PubMed]

168. Lozano-Duran, R. Geminiviruses for biotechnology: The art of parasite taming. New Phytol. 2016, 210, 58-64. [CrossRef] [PubMed]

169. Hefferon, K.L. DNA virus vectors for vaccine production in plants: Spotlight on geminiviruses. Vaccines 2014, 2, 642-653. [CrossRef] [PubMed]

170. Gilbertson, R.L.; Batuman, O.; Webster, C.G.; Adkins, S. Role of the insect supervectors Bemisia tabaci and Frankliniella occidentalis in the emergence and global spread of plant viruses. Annu. Rev. Virol. 2015, 2, 67-93. [CrossRef] [PubMed]

171. Jeske, H.; Lütgemeier, M.; Preiss, W. Distinct DNA forms indicate rolling circle and recombination-dependent replication of Abutilon mosaic geminivirus. EMBO J. 2001, 20, 6158-6167. [CrossRef] [PubMed]

172. Preiss, W.; Jeske, H. Multitasking in replication is common among geminiviruses. J. Virol. 2003, 77, $2972-2980$. [CrossRef] [PubMed]

173. Alberter, B.; Rezaian, A.M.; Jeske, H. Replicative intermediates of ToLCV and its satellite DNAs. Virology 2005, 331, 441-448. [CrossRef] [PubMed]

174. Morilla, G.; Castillo, A.G.; Preiss, W.; Jeske, H.; Bejarano, E.R. A versatile transreplication-based system to identify cellular proteins involved in geminivirus replication. J. Virol. 2006, 80, 3624-3633. [CrossRef] [PubMed]

175. Jovel, J.; Preiss, W.; Jeske, H. Characterization of DNA intermediates of an arising geminivirus. Virus Res. 2007, 130, 63-70. [CrossRef] [PubMed]

176. Erdmann, J.B.; Shepherd, D.N.; Martin, D.P.; Varsani, A.; Rybicki, E.P.; Jeske, H. Replicative intermediates of maize streak virus found during leaf development. J. Gen. Virol. 2010, 91, 1077-1081. [CrossRef] [PubMed]

177. Ruschhaupt, M.; Martin, D.P.; Lakay, F.; Bezuidenhout, M.; Rybicki, E.P.; Jeske, H.; Shepherd, D.N. Replication modes of maize streak virus mutants lacking repA or the repA-pRBR interaction motif. Virology 2013, 442, 173-179. [CrossRef] [PubMed]

178. Richter, K.S.; Jeske, H. Ku80, a key factor for non-homologous end-joining, retards geminivirus multiplication. J. Gen. Virol. 2015, 96, 2913-2918. [CrossRef] [PubMed]

179. Richter, K.S.; Ende, L.; Jeske, H. Rad54 is not essential for any geminiviral replication mode in planta. Plant Mol. Biol. 2015, 87, 193-202. [CrossRef] [PubMed]

180. Richter, K.S.; Gotz, M.; Winter, S.; Jeske, H. The contribution of translesion synthesis polymerases on geminiviral replication. Virology 2016, 488, 137-148. [CrossRef] [PubMed]

181. Saunders, K.; Lucy, A.; Stanley, J. DNA forms of the geminivirus African cassava mosaic virus consistent with a rolling circle mechanism of replication. Nucleic Acids Res. 1991, 19, 2325-2330. [CrossRef] [PubMed]

182. Saunders, K.; Lucy, A.; Stanley, J. RNA-primed complementary-sense DNA synthesis of the geminivirus African cassava mosaic virus. Nucleic Acids Res. 1992, 20, 6311-6315. [CrossRef] [PubMed]

183. Dean, F.B.; Nelson, J.R.; Giesler, T.L.; Lasken, R.S. Rapid amplification of plasmid and phage DNA using phi 29 DNA polymerase and multiply-primed rolling circle amplification. Genome Res. 2001, 11, 1095-1099. [CrossRef] [PubMed]

184. Jeske, H.; Gotthardt, D.; Kober, S. In planta cloning of geminiviral DNA: The true Sida micrantha mosaic virus. J. Virol. Methods 2010, 163, 301-308. [CrossRef] [PubMed]

185. Gutierrez, C.; Suarez-Lopez, P.; Ramirez-Parra, E.; Sanz-Burgos, A.; Poenninger, J.; Xie, Q. DNA bending as a potential regulatory cis-acting element of the geminivirus intergenic region. Agronomie 1995, 15, 415-420. [CrossRef]

186. Richter, K.S.; Serra, H.; White, C.I.; Jeske, H. The recombination mediator rad51D promotes geminiviral infection. Virology 2016, 493, 113-127. [CrossRef] [PubMed]

187. Finney, D.J. Probit Analysis; Cambridge University Press: London, UK, 1952.

188. Gallet, R.; Fabre, F.; Michalakis, Y.; Blanc, S. The number of target molecules of the amplification step limits accuracy and sensitivity in ultra deep sequencing viral population studies. J. Virol. 2017. [CrossRef] [PubMed]

189. Duffy, S.; Holmes, E.C. Multiple introductions of the old world begomovirus tomato yellow leaf curl virus into the New World. Appl. Environ. Microbiol. 2007, 73, 7114-7117. [CrossRef] [PubMed]

190. Romay, G.; Chirinos, D.; Geraud-Pouey, F.; Desbiez, C. Association of an atypical alphasatellite with a bipartite New World begomovirus. Arch. Virol. 2010, 155, 1843-1847. [CrossRef] [PubMed] 
191. Hipp, K.; Rau, P.; Schafer, B.; Pfannstiel, J.; Jeske, H. Translation, modification and cellular distribution of two AC4 variants of African cassava mosaic virus in yeast and their pathogenic potential in plants. Virology 2016, 498, 136-148. [CrossRef] [PubMed]

192. Stenger, D.C.; Revington, G.N.; Stevenson, M.C.; Bisaro, D.M. Replicational release of geminivirus genomes from tandemly repeated copies: Evidence for rolling-circle replication of a plant viral DNA. Proc. Natl. Acad. Sci. USA 1991, 88, 8029-8033. [CrossRef] [PubMed]

193. Hellens, R.P.; Edwards, E.A.; Leyland, N.R.; Bean, S.; Mullineaux, P.M. Pgreen: A versatile and flexible binary Ti vector forAgrobacterium-mediated plant transformation. Plant Mol. Biol. 2000, 42, 819-832. [CrossRef] [PubMed]

194. Mehta, D.; Hirsch-Hoffmann, M.; Patrignani, A.; Gruissem, W.; Vanderschuren, H. Cider-seq: Unbiased virus enrichment and single-read, full length genome sequencing. bioRxiv 2017. [CrossRef]

195. Korlach, J.; Bjornson, K.P.; Chaudhuri, B.P.; Cicero, R.L.; Flusberg, B.A.; Gray, J.J.; Holden, D.; Saxena, R.; Wegener, J.; Turner, S.W. Real-time DNA sequencing from single polymerase molecules. In Methods in Enzymology; Walter, N.G., Ed.; Academic Press: Cambridge, MA, USA, 2010; Volume 472, pp. 431-455.

196. Zamir, D. Farewell to the lose-lose reality of policing plant imports. PLoS Biol. 2016, 14, e1002438. [CrossRef] [PubMed]

(C) 2018 by the author. Licensee MDPI, Basel, Switzerland. This article is an open access article distributed under the terms and conditions of the Creative Commons Attribution (CC BY) license (http://creativecommons.org/licenses/by/4.0/). 